In Corporeal Generosity Rosalyn Diprose pursues a novel approach to one of the central topics in contemporary scholarly and practical ethical debates: how to conceive and promote ethical relations responsive to the differences of others. The ghost behind this problem is the Kantian conception of ethics. The noumenal, moral capacity of the Kantian subject is, famously, a

\title{
the ethics of
}

\section{embodiment} formal idea of reason. Through it the subject houses a double potential: to act against the sensuous promptings of the body, and to mould or form material circumstances against their claim to be the source for action. In Diprose's

ROSALYN DIPROSE

Corporeal Generosity: On Giving with Nietzsche, Merleau-Ponty, and Levinas

SUNY Press, Albany, New York, 2002 ISBN 0-79145-322-7

RRP US\$20.95 (pb) 
surrogacy rights and the treatment of indigenous populations in Australia). But her notion of 'corporeal generosity' is also deployed to question the works of thinkers, including Butler, Foucault, Nietzsche, Sartre, Beauvoir and Levinas, who fuse the topics of embodiment and ethics but overlook the prior claims of generosity.

So, what exactly is meant by this notion of 'corporeal generosity'? There are two possible ways of understanding its scope and implications. First, and negatively, it targets the primacy given to contemplative, deliberative action according to which ethical relations fall under the jurisdiction of an autonomous subject; and second, and more positively, it uses phenomenological writing as well as work by Nietzsche to argue for the body as the prior site of ethical relations (reconceived as inter-corporeal relations) in which the self is already given to and by others. In both of these respects the author revisits the emphasis on bodily affect in the Nietzschean and phenomenological traditions. 'Corporeal generosity' significantly expands on these traditions by allowing, against Nietzsche, for the importance of the gift of others in the constitution of the self, and, against phenomenology, for the social and historical encoding of bodies. But the ontological primacy of corporeal generosity is not just a way of recoding ethical relations or rethinking the affective dimension of interpersonal relations'. (75) Rather Diprose uses this idea for political effect. She shows how even when the gift of bodies is recognised in an institutional practice (such as the biomedical alienation of bodily tissues in surrogacy) the 'gift' can be forced, and further that the authority we 'invest in the law ... to determine the origin and destination of gifts' usually forgets the giving of women and remembers that of men. (56-8)

Diprose thus develops an idea that spans the analysis of philosophical texts as well as social and institutional practices. The benefits of this idea for the formulation of a new concept of bodily affect will be apparent to all who read it. On the other hand, I suspect that the debate over this book will focus on the sociopolitical claims attached to this concept. As Diprose explains in her introduction, the idea of "corporeal generosity' has a double function: at once it explores 'the role of inter-corporeal relations in the social production, maintenance, or effacement of differences' and it aims to promote 'ways to foster social relations that generate rather than close off sexual, cultural, and stylistic differences'. (15) The book gives superb accounts of the social role of inter-corporeal relations, but also honestly engages with the considerable political difficulties raised by the problem of promoting social relations that 'generate ... sexual, cultural, and stylistic differences'. The urgency of promoting such social relations lies in the effects of a stunted conception of justice as the calculation and remediation of wrongs. In Diprose's account this conception relies on the view that generosity is 'a virtue built by habit informed by existing imaginaries' and thereby overlooks the way that certain 'bodies dominate and extract privilege in this exchange economy'. (184) Like Deleuze, Diprose thinks that events force us to think and that these events comport a novelty that throws into question prevailing habit-bound imagin- 
aries. But she finds more in common with Derrida than Deleuze when she tries to give this event the status of a rationale for action. ${ }^{2}$

The latter part of the book draws on the Derridean conception of justice as that which places on us a necessary injunction to act, despite and also because of the real injustice that would not be able to be met or compensated for by any act. The examples in her chapter on decolonisation are instructive in this regard: the systematic removal of children from Aboriginal families in Australia in the 1960s is a wrong that is unable to be adequately remedied. Her reflections on the topic of justice aim to sustain an ethical relation that recognises the necessity to act despite the absence of any program able to guide such action to a just end. Furthermore it is just this ethical model that, as in works by Rancière and Lyotard on the topic of injustice, ${ }^{3}$ encourages new ways of thinking, being and acting to meet the political claims that historical wrongs make upon us. In Diprose's case the imperialism of familiar ideas 'effect a closure to difference in cultural as well as self-formation'. (145) The author's account of the effects of the denial of 'corporeal generosity' and her identification of its antidote in the need to promote 'sexual, cultural and stylistic differences' raise a number of problems for further debate.

Diprose discusses these problems towards the end of her book. Among them, how do new ideas emerge? Is this model of 'corporeal generosity' able to explain how they are generated? If it is, and the author gives a number of examples from recent feminist philosophy to show this process at work, is the framework of this book attentive to the social forces that block the pro- duction of novelty? How do questions of lifestyle politics and its toleration of difference relate to broader political trends? ${ }^{4}$ For Diprose the validation of difference provides the evaluative framework that discriminates between a novelty attentive to ethical claims and the forces that stymie such claims. In this respect this book offers an important contribution to the future elaboration of an ethics that neither overrules the body nor tells us how to act.

ALISON ROSS teaches at Monash University, Melbourne.

1. Friedrich Nietzsche, On the Genealogy of Morals and Ecce Homo, trans. Walter Kaufmann, Random House, New York, 1969. See the third essay, in particular sections 7-13 where he complains about the ascetism of philosophers in terms of their hostility to the body and its affects.

2. The discussion of Deleuze is restricted to the discussion of the creation of new concepts in his work with Guattari: What is Philosophy?, trans. G. Burchell and H.Tomlinson, Verso, London, 1994. Although it is understandable why phenomenology provides the framework for many of the analyses in the book the prominent place given to eroticism suggests links to the libidinalised conception of social flows in Deleuze and Guattari's two volume Capitalism and Schizophrenia Anti-Oedipus, trans. R. Hurley, M. Seem and H.R. Lane, University of Minnesota Press, Minneapolis, 1983; A Thousand Plateaus, trans. Brian Massumi, University of Minnesota Press, Minneapolis, 1987.

3. See Jacques Rancière, On the Shores of Politics, trans. Liz Heron, Verso, London and New York, 1995, and Jean-François Lyotard, The Differend: Phrases in Dispute, trans. Georges Van Den Abeele, University of Minnesota Press, Minneapolis, 1988, for such accounts.

4. The conjunction of both sets of questions in Michel Foucault's work is important precisely because it does not untangle the operation of biopower and governmentality from the account of the practices of the medical clinic, the law and the social policing of sexualities. 